\title{
STUDI PEMIKIRAN PROF. YUSRIL IHZA MAHENDRA TENTANG TRANSFORMASI SYARI'AT ISLAM KE DALAM HUKUM NASIONAL
}

\author{
Mohammad Masduki \\ Advokat dan Direktur Utama PT. Rekabumi Intiland Propertindo \\ Email :gusmasduki@gmail.com
}

\begin{abstract}
Abstrak
Indonesia adalah negara dengan penduduk mayoritas beragama Islam. Menurut perhitungan statistik yang dikeluarkan pemerintah pada tahun 2010, sebanyak 87,18 persen penduduk Indonesia adalah muslim. Sistem hukum yang berlaku di Indonesia adalah sistem hukum campuran (Mix Legal System), yakni hukum Eropa Kontinental, hukum adat, hukum Islam, dan bahkan Anglo Saxon. Yusril Ihza Mahendra merupakan salah satu tokoh nasional dan pakar hukum tata negara yang tertarik dalam persoalan transformasi Syari'at Islam ke dalam Hukum Nasional. Tujuan dari penelitian ini yaitu untuk menganalisis pemikiran Yusril Ihza Mahendra tentang Transformasi Syari'at Islam ke dalam Hukum Nasional. Penelitian ini menggunakan jenis penelitian hukum normatif. Sehingga metode pengambilan bahan hukum menggunakan metode kepustakaan dan wawancara langsung. Yusril Ihza Mahendra mengatakan transformasi Syari'at Islam ke dalam Hukum Nasional sangat relevan untuk dilaksanakan di Indonesia, mengingat Indonesia adalah negara yang mayoritas berpenduduk muslim. Suatu undangundang akan berjalan dengan baik dan efektif apabila substansinya sesuai dengan keyakinan masyarakat itu sendiri, dimana hukum Islam adalah hukum yang hidup di tengah-tengah masyarakat Indonesia. Transformasi syariat Islam ke dalam hukum nasional memerlukan proses perubahan bentuk (transformasi) dan perumusan (formulasi) kaidah-kaidah hukum Islam yang bersumber dari ayat-ayat Quran dan Hadis hukum (syariat Islam) ke dalam hukum nasional melalui pembentukan peraturan perundang-undangan (proses legislasi). Untuk itu diperlukan institusi-institusi kekuasaan negara atau daulah yang sah yang berfungsi untuk menegakkan norma hukum nasional agar dipatuhi dan dijalankan oleh publik. Proses pembentukan peraturan perundang-undangan yang (sebagian) bersumber dari syariat Islam merupakan sebuah proses politik. Hal ini memerlukan kesadaran dengan menumbuhkan jiwa Islami kepada para penguasa, karena mereka yang punya hak dalam perancangan dan pengesahan suatu peraturan perundang-undangan.
\end{abstract}

Kata kunci: Transformasi, Syari'at Islam, Hukum Nasional

\section{Abstract}

Indonesia is a country with a majority Muslim population. Statistical calculations released by the government shows that that 87.18 percent of Indonesia's population is Muslim. However, the current applicable legal system is the Continental European legal system, the Anglo Saxon legal system and a small part of customary law and Islamic law. Yusril Ihza Mahendra is one of the 


\section{Jurnal Negara dan $\mathcal{X}$ eadilan \\ p-ISSN 2302-7010 e-ISSN 2721-9801}

national figures and experts in constitutional law who is interested in the issue of the transformation of Islamic Shari'ah into National Law. This study aims to analyze Yusril Ihza Mahendra's thoughts on the Transformation of Islamic Shari'ah into National Law. The type of this research is normative legal research. So that the taking of legal materials using the library method is reinforced by direct interviews. Yusril Ihza Mahendra said that the transformation of Islamic Shari'ah into national law was very relevant to implement, considering that Indonesia is a country with a majority Muslim population. Legislative drafting that is in line with the community's beliefs will likely work, whereas Islamic law is the living law in Indonesian society. However various formulation processes are required. That is by formulating the principles of Islamic law and then pouring it into a form that can be implemented in reality. In addition, it is necessary to have institutions of power called legitimate state to impose a legal norm so that it is carried out and obeyed by the public. Furthermore, the process of legislative drafting is the political process. This process requires awareness by cultivating an Islamic spirit of the rulers because they have the right to draft regulation or legislation.

Keywords: Transformation, Islamic Shari'ah, National Law

\section{PENDAHULUAN}

Indonesia adalah negara dengan penduduk mayoritas beragama Islam. Menurut perhitungan statistik resmi yang dikeluarkan pemerintah pada tahun 2010, sebanyak 87,18 persen penduduk Indonesia adalah muslim. ${ }^{1}$ Namun demikian sistem hukum yang berlaku adalah sistem hukum Eropa Kontinental (civil law system), sistem hukum anglo saxon (common law system), dan sebagian kecil hukum adat dan hukum Islam. ${ }^{2}$ Dalam pemikiran Yusril Ihza Mahendra Hukum Islam adalah the living law atau hukum yang hidup di tengah-tengah masyarakat. ${ }^{3}$ Hukum Islam bukan ius constitutum (hukum yang berlaku saat ini atau hukum positif) dan bukan pula ius constituendum (hukum yang dicita-citakan atau yang diangan-angankan di masa mendatang). Hukum positif adalah hukum yang diformulasikan oleh negara dan dalam pelaksanaannya tegas dinyatakan berlaku atau tidak berlaku lagi. Sedangkan the living law tidak diformulasikan oleh negara, tetapi hukum tersebut hidup di dalam alam pikiran dan kesadaran hukum masyarakat.

Secara teoritis, ada perbedaan antara "hukum positif" dengan "hukum yang hidup". Hukum positif (tertulis) disahkan keberlakuannya oleh negara berdasarkan prosedur yang ditentukan konstitusi atau aturan-aturan lain yang berlaku di suatu negara. Sehingga dapat dikatakan hukum positif adalah produk dari kekuatan-kekuatan politik yang melahirkannya. Sedangkan hukum yang hidup adalah hukum yang tersosialisasikan dan diterima oleh masyarakat secara persuasif, karena dianggap sesuai dengan kesadaran hukum dan keadilan.

${ }^{1}$ BPS. 2010. Penduduk Menurut Wilayah dan Agama yang dianut. https://sp2010.bps.go.id/ index.php/site/ tabel?tid=321\&wid=0. 03/11/2020

${ }^{2}$ Satjipto Rahardjo, Ilmu Hukum, Bandung: Citra Aditya, 2000, hlm. 235

${ }^{3}$ Abbas, Hafid, et.all, Ensiklopedia Pemikiran Yusril Ihza Mahendra, Buku Tiga, Jakarta: Pro Deleader. hlm. 7 


\section{$\mathcal{H}$ urnal Negara dan Keadilan \\ p-ISSN 2302-7010 e-ISSN 2721-9801}

Dilihat dari sejarah kerajaan-kerajaan Islam di Nusantara pada masa lampau, upaya untuk menerapkan ajaran-ajaran dan hukum Islam mendapat dukungan besar, baik dari kalangan para ulama', penguasa politik, bahkan rajaraja dan para sultan ${ }^{4}$. Berbagai kitab hukum ditulis oleh para ulama', kerajaan dan kesultanan pada masa tersebut dan juga telah menjadikan hukum Islam dibidang hukum keluarga dan hukum perdata sebagai hukum positif yang berlaku. Selain itu kerajaan juga membangun masjid besar di ibu kota negara.

Pada abad ke-17 Pelaksanaan hukum Islam juga dilakukan oleh para penghulu dan para kadi di daerah sekitar Batavia, masyarakat islam setempat mengangkat sendiri para penghulu dan para kadi apabila tidak terdapat kekuasaan politik formal yang mendukung pelaksanaan ajaran dan hukum Islam. Di pulau Jawa, masyarakat Jawa, Sunda, dan Banten mengembangkan hukum Islam melalui Pendidikan sebagai mata pelajaran penting di pondok-pondok pesantren.

Di masa sebelum kemerdekaan, dalam sidang BPUPKI tokoh-tokoh Islam menginginkan agar di negara Indonesia harus berdasarkan atas Ketuhanan dengan kewajiban menjalankan syariat Islam bagi pemeluk-pemeluknya, seperti yang disepakati dalam Piagam Jakarta tanggal 22 Juni 1945, namun kalimat ini dihilangkan setelah terjadi keberatan dari para tokoh Indonesia bagian timur atas pemakaian kata tersebut. Hal ini disampaikan oleh seorang perwira angkatan Laut Jepang kepada Mohammad Hatta pada sore hari tanggal 17 Agustus 1945. Untuk menghindari perpecahan, keesokan harinya pada tanggal 18 Agustus 1945, sebelum sidang PPKI dimulai, Hatta mengadakan pembicaraan dengan tokohtokoh Islam, yakni KH Abdul Wahid Hasyim, Teuku Muhammad Hasan, dan Ki Bagus Hadikusumo tentang rencana perubahan kata-kata dalam Piagam Jakarta. Akhirnya ketiga tokoh tersebut menerima penghapusan tujuh kata menjadi Ketuhanan yang Maha Esa dan berlaku hingga saat ini. ${ }^{5}$ Dengan melihat sejarah hukum Islam yang berkembang di Indonesia sejak dulu sudah seharusnya ajaran Islam menjadi sumber hukum dalam pembangunan hukum nasional.

Islam sebagai agama universal, mengandung aspek-aspek keruhanian yang berhubungan dengan iman dan moralitas, pengaturan kehidupan bermasyarakat, berbangsa, bernegara, dan menyangkut berbagai aspek dalam tata hubungan antarbangsa.

Syariat Islam menurut Ibnu Taymiyyah merupakan keseluruhan ajaran Islam yang dijumpai di dalam Al Qur-an dan Al Hadits. Sedangkan menurut Zainuddin Ali, Syariat Islam tidak hanya memuat hukum-hukum shalat, zakat, puasa, melainkan juga mengandung hukum-hukum dunia baik keperdataan maupun kepidanaan yang memerlukan kekuasaan negara untuk menjalankannya secara sempurna. ${ }^{6}$

Pengaruh Hukum Islam di bidang hukum keluarga dirasakan lebih besar oleh masyarakat dibandingkan dengan bidang-bidang hukum lainnya. Bidang hukum keluarga yang mengatur tentang hukum perkawinan, perwalian, dan kewarisan. Di dalam bidang hukum keluarga, hukum Islam menjadi kesadaran hukum yang berlaku secara langsung bagi penduduk yang beragama Islam.

\footnotetext{
${ }^{4}$ Ibid, hlm 21

${ }^{5}$ Fathoni R.S. Piagam Jakarta 22 Juni 1945. 2018.https://wawasansejarah.com/ piagamjakarta/.03/11/2020

${ }^{6}$ Ali, Zainuddin, Hukum Perdata Islam di Indonesia, Cetakan kelima, Jakarta: Remaja Rosdakarya, 2006, hlm. 2
} 


\section{Jurnal Negara dan Keadilan \\ p-ISSN 2302-7010 e-ISSN 2721-9801}

Sehingga pemerintah dan badan-badan perwakilan tidak mempunyai pilihan lain selain mengangkat status hukum Islam di bidang ini menjadi hukum nasional yang berlaku khusus bagi penduduk yang beragama Islam.

Jika dibandingkan dengan kecepatan perubahan sosial yang terjadi di masyarakat, Pembangunan hukum di Indonesia terasa berjalan lamban. Kelambanan tersebut terjadi pada pembangunan materi hukum, yaitu menciptakan produk-produk hukum baru untuk memenuhi kebutuhan hukum masyarakat, juga dalam pembangunan aparatur hukum serta pengadaan sarana dan prasarana hukum. ${ }^{7}$

Menurut berbagai kajian ilmiah untuk mencapai mekanisme hukum yang kuat diperlukan adanya keteraturan sosial, ketertiban, dan kepastian hukum. Sehingga hukum yang kuat tersebut akan berdampak pada kemajuan dalam pembangunan ekonomi.

Berdasarkan uraian di atas, sudah seharusnya bangsa Indonesia memiliki pijakan hukum yang kuat yang berlandaskan pada suatu agama yang dianut oleh mayoritas penduduk Indonesia, yakni agama Islam, yang kaidah-kaidah hukumnya telah hidup, tumbuh dan berkembang ditengah-tengah masyarakat sudah selayaknya menjadi sumber rujukan bagi pembaharuan hukum nasional.

Yusril Ihza Mahendra merupakan salah satu tokoh nasional dan pakar hukum tata negara, yang tertarik dalam persoalan transformasi syariat Islam ke dalam hukum Nasional. Pemikiran dan karya-karya dalam mentransformasi syariat Islam ke dalam Hukum Nasional telah banyak memberikan perubahan dalam pembangunan hukum di Indonesia baik selama berada di dalam kabinet pemerintahan maupun di luar pemerintahan.

Penelitian ini mengkaji dan ingin menjawab rumusan masalah yang diajukan yakni: (a) Bagaimana pemikiran Yusril Ihza Mahendra tentang Syari'at Islam?, (b) Bagaimana pemikiran Yusril Ihza Mahendra tentang Hukum Islam sebagai Sumber Hukum Nasional?, dan (c) Bagaimana pemikiran Yusril Ihza Mahendra tentang Transformasi Syari'at Islam ke dalam Hukum Nasional?

Jenis penelitian yang digunakan adalah penelitian hukum normatif (normative law research), yaitu penelitian hukum yang mengkaji hukum tertulis dari berbagai aspek, yaitu aspek teori, sejarah, filosofis, perbandingan, struktur dan komposisi, lingkup dan materi, konsistensi, penjelasan umum pasal demi pasal, formalitas dan kekuatan mengikat suatu undang-undang, serta bahasa hukum yang digunakan, tetapi tidak mengkaji aspek terapan atau implementasinya. ${ }^{8}$

Penelitian hukum normatif atau atau penelitian hukum kepustakaan adalah penelitian hukum yang dilakukan dengan cara meneliti bahan pustaka atau data sekunder belaka. ${ }^{9}$ Pada penelitian hukum normatif, bahan pustaka merupakan data dasar yang dalam ilmu penelitian digolongkan sebagai data sekunder. ${ }^{10}$

Tipe penelitian hukum yang dilakukan adalah yuridis normatif terhadap pemikiran Yusril Ihza Mahendra dalam analisis pentransformasian Syari'at Islam

\footnotetext{
${ }^{7}$ Abbas, Hafid, et.al, op. cit., hlm 23

${ }^{8}$ Anonim, 2013. "Pendekatan dalam Penelitian Hukum". https://ngobrolinhukum. wordpress.com/2013/12/16/ pendekatan-dalam-penelitian-hukum/. Diakses 12/12/2020

${ }^{9}$ Soerjono Soekanto dan Sri Mamudji. Penelitian Hukum Normatif Suatu Tinjauan Singkat. Jakarta: Rajawali Pers, 2006. Hlm 13

${ }^{10}$ Ibid., Hlm 24
} 


\section{$\mathcal{H}$ urnal Negara dan $\mathcal{X}$ eadilan \\ p-ISSN 2302-7010 e-ISSN 2721-9801}

kedalam Hukum Nasonnal. Penelitian yuridis normatif adalah penelitian atas hukum yang dikonsepsikan dan dikembangkan atas dasar doktrin yang dianut atau juga disebut penelitian perpustakaan atau studi dokumen. Sehingga metode pengambilan bahan hukum yang digunakan menggunakan metode telaah kepustakaan yang diperkuat dengan wawancara langsung dengan Prof. Yusril Ihza Mahendra.

\section{METODE PENELITIAN}

Pendekatan penelitian yang digunakan pada penelitian ini adalah pendekatan historis (historical approach) dan pendekatan konsep (conceptual approach). Pendekatan historis adalah pendekatan yang digunakan untuk mengkaji latar belakang apa yang dipelajari dan perkembangan pengaturan mengenai masalah yang dihadapi dalam kontek kesejarahannya. ${ }^{11}$ Dalam penelitian ini pendekatan historis dilakukan dalam kerangka untuk memahami transformasi Syariat Islam ke dalam Hukum Nasional dari kurun waktu ke waktu, serta untuk memahami perubahan dan perkembangan filosofi yang melandasi aturan hukum tersebut.

Pendekatan konsep adalah pendekatan yang berkaitan dengan konsepkonsep yuridis atau pandangan-pandangan (doktrin) yang berkaitan dengan masalah yang akan diteliti. ${ }^{12}$ Dengan pendekatan konseptual ini, peneliti akan menemukan ide-ide yang melahirkan konsep-konsep yang berkaitan dengan permasalahan yang diteliti. Pendekatan konsep dalam penelitian ini untuk memahami pandangan Yusril Ihza Mahendra mengenai transformmasi syariat Islam ke dalam hukum nasional yang berkembang dalam ilmu hukum dan dapat menjadi pijakan untuk membangun argumen hukum dalam menyelesaikan isu hukum yang dihadapi.

Dilihat dari sudut sifat informasi yang diberikan dalam penelitian hukum kepustakaan, bahan pustaka dapat dibagi dalam dua kelompok. Yaitu, Sumber Bahan Primer dan Sumber Bahan Sekunder. Sumber bahan primer adalah bahan pustaka yang berisi pengetahuan ilmiah yang baru atau mutakhir, ataupun pengertian baru tentang fakta yang diketahui maupun mengenai suatu gagasan atau ide. ${ }^{13}$ Sedangkan Sumber bahan sekunder adalah bahan pustaka yang berisi informasi tentang bahan primer. ${ }^{14}$

Penelitian ini menggunakan sumber bahan primer maupun sumber bahan sekunder. Didalam penelitian hukum normatif, dari sudut kekuatan mengikatnya, bahan pustaka bidang hukum dapat dibedakan menjadi tiga golongan yakni bahan hukum primer, sekunder, dan tersier. ${ }^{15}$ Bahan hukum primer, yaitu bahan-bahan hukum yang mengikat. Bahan hukum sekunder, yaitu bahan hukum yang memberikan penjelasan mengenai bahan hukum primer. Dan Bahan hukum tersier, yakni bahan yang memberikan petunjuk maupun penjelasan terhadap bahan hukum primer dan sekunder. ${ }^{16}$

\footnotetext{
${ }^{11}$ Anonim, 2013. Loc.cit

12 Ibid.,

${ }^{13}$ Soerjono Soekanto dan Sri Mamudji. Op.cit., hlm 28

${ }^{14}$ Ibid.,

15 Ibid., hlm 32

${ }^{16}$ Ibid., hlm 12
} 


\section{Zurnal Negara dan $\mathcal{X}$ eadilan \\ p-ISSN 2302-7010 e-ISSN 2721-9801}

Sepanjang penelusuran sumber bahan hukum yang dilakukan, belum ditemukan bahan hukum primer terkait penelitian ini, yakni peraturan-peraturan yang mengatur tentang transformasi syari'at Islam ke dalam hukum nasional. Selain itu, fokus penelitian ini adalah meneliti konsep dan pokok-pokok pemikiran Yusril Ihza Mahendra terkait proses transformasi syari'at Islam ke dalam hukum nasional. Oleh karena itu penelitian ini hanya menggunakan bahan hukum sekunder dan bahan hukum tersier.

Guna mendukung bahan hukum sekunder dan tersier tersebut dilakukan wawancara langsung dengan Prof. Yusril Ihza Mahendra sebagai ahli hukum yang memiliki pemikiran tentang transformasi syari'at Islam ke dalam hukum nasional. Wawancara dilakukan melalui media elektronik dengan alat perekam suara, foto, dan camera video. Dalam penelitian ini karena kondisi pandemi Covid-19 wawancara dilakukan secara virtual menggunakan aplikasi Zoom Meeting. Peneliti mengajukan pertanyaan-pertanyaan terkait rumusan masalah penelitian dan pandangan visioner kenegaraan Prof. Yusril Ihza Mahendra. Hasil wawancara yang berupa rekaman suara kemudian dikonversi kedalam teks tertulis. Naskah tertulis hasil wawancara ini menjadi bagian dari bahan hukum yang akan dianalisis guna menjawab rumusan masalah penelitian.

\section{PEMBAHASAN}

\section{Pemikiran Yusril Ihza Mahendra tentang Syariat Islam}

Yusril Ihza Mahendra membatasi syariat Islam hanya kepada ayat-ayat Al Qur-an dan hadits-hadits yang secara eksplisit mengandung suatu norma hukum didalamnya. Dalam bukunya yang berjudul Ensiklopedia Pemikiran Yusril Ihza Mahendra, ${ }^{17}$ Yusril menjelaskan mengenai pengertian syariat Islam ada perbedaan pandangan di kalangan para ahli. Ibnu Taimiyyah misalnya berpendapat bahwa keseluruhan ajaran Islam yang dijumpai di dalam Al Qur-an dan Al Hadits itu adalah syariat Islam. Namun Prof. Yusril Ihza Mahendra mengatakan untuk kepentingan studi ilmu hukum pengertian yang sangat luas tersebut tidak banyak membantu.

Dengan pembatasan seperti tersebut di atas, maka dengan merujuk kepada pendapat Abdul Wahhab al-Khallaf, maka kaidah-kaidah hukum dalam syariah itu baik di bidang peribadatan maupun di bidang mu'amalah tidaklah banyak jumlahnya. ${ }^{18}$ Al-Khallaf menyebutkan ada 228 ayat Al Qur-an yang dapat dikategorikan mengandung kaidah-kaidah hukum di bidang mu'amalah, atau sekitar 3 persen dari keseluruhan ayat-ayat Al Qur-an. Pengertian Syariah Islam menurut Prof. Yusril Ihza Mahendra adalah ayat-ayat Al Qur-an dan hadits-hadits Rasulullah SAW yang di dalamnya mengandung suatu norma hukum. Apabila suatu ayat atau hadits Rasulullah SAW tidak mengandung suatu norma hukum, maka ayat atau hadits tersebut tidak termasuk sebagai syariat.

\footnotetext{
${ }^{17}$ Abbas, Hafid, et.all,. op.cit.,Hlm 28

18 Ibid.,
} 


\section{Jurnal Negara dan Keadilan \\ p-ISSN 2302-7010 e-ISSN 2721-9801}

\section{Pemikiran Yusril Ihza Mahendra tentang Hukum Islam sebagai Sumber Hukum Nasional}

Menurut Pemikiran Yusril Ihza Mahendra, sepanjang telaahnya tentang sejarah hukum di Indonesia, sejak berabad-abad yang lalu, hukum Islam telah menjadi hukum yang hidup di tengah-tengah masyarakat Islam di Indonesia. Hal ini dapat dilihat dari banyaknya pertanyaan yang disampaikan masyarakat seputar hukum Islam melalui majalah dan koran, untuk dijawab oleh seorang ulama atau seorang yang mengerti tentang hukum Islam. Seperti contoh organisasi-organisasi Islam menerbitkan buku-buku himpunan fatwa, yang berisi bahasan mengenai soal-soal hukum Islam. Kaum Nahdhiyin mempunyai Al-Ahkamul Fuqoha, dan Kaum Muhammadiyin mempunyai Himpunan Putusan Tarjih, dan lain-lain. ${ }^{19}$

Dalam menjalankan kehidupan sehari-hari, baik sebagai pribadi, keluarga, dan masyarakat, umat Islam menyadari ada aspek-aspek hukum yang mengatur kehidupannya dimana aturan tersebut perlu mereka taati dan jalankan dengan penuh kesadaran. Seberapa besar kesadaran itu, akan sangat tergantung kepada komposisi besar kecilnya komunitas umat Islam, seberapa jauh ajaran Islam diyakini dan diterima oleh individu dan masyarakat, dan sejauh mana pengaruh dari pranata sosial dan politik dalam memperhatikan pelaksanaan ajaran-ajaran Islam dan hukum-hukumnya dalam kehidupan masyarakat. ${ }^{20}$

Sejarah kerajaan-kerajaan Islam di Nusantara pada masa lampau, upaya untuk melaksanakan ajaran-ajaran Islam, termasuk hukum-hukumnya, nampak mendapat dukungan yang besar, bukan dari para ulama' saja, tetapi juga dukungan penguasa politik, yakni para raja dan para sultan. Jejak peninggalan kehidupan sosial keagamaan Islam dan pranata hukum Islam tersebut masih bisa kita saksikan sampai sekarang. Seperti, di Kesultanan Aceh, Deli, Palembang, Goa dan Tallo di Sulawesi Selatan, Kesultanan Buton, Bima, Banjar serta Ternate dan Tidore. Juga di Yogyakarta, Surakarta, dan Kesultanan Banten dan Cirebon di Jawa. Semua kerajaan dan kesultanan tersebut telah memberikan tempat yang begitu penting bagi hukum Islam. ${ }^{21}$

\section{Pemikiran Yusril Ihza Mahendra tentang Transformasi Syariat Islam ke dalam Hukum Nasional}

Menurut pemikiran Yusril Ihza Mahendra, Al Qur-an adalah "hudan linnas" (petunjuk bagi manusia) dan bukan sebagai kitab hukum atau naskah sebuah undang-undang. Ayat-ayat ahkam di dalam Al Qur-an perlu dirumuskan ke dalam hukum positif seperti undang-undang untuk dilaksanakan dalam praktik. Apabila ada perkara, hakim akan memutus dengan merujuk pada undang-undang tersebut. ${ }^{22}$ Dalam ilmu hukum, yang dimaksud "hukum posiitif" adalah hukum yang berlaku di suatu negara tertentu dan pada waktu tertentu. Jadi, bukan positif menurut agama tertentu dan tidak positif menurut agama lain. ${ }^{23}$

Indonesia adalah negara yang majemuk. Kemajemukan itu tercermin pula pada keanekaragamaan hukumnya. Untuk hukum privat seperti hukum perkawinan dan hukum waris, tidak mungkin ada penyeragaman atau unifikasi

\footnotetext{
${ }^{19}$ Ibid hlm 21

${ }^{20}$ Ibid.,

21 Ibid.,

22 Ibid., hlm 37

23 Ibid.,
} 


\section{Zurnal Negara dan $\mathcal{X}$ eadilan \\ p-ISSN 2302-7010 e-ISSN 2721-9801}

hukum. Hukum diberlakukan kepada warga negara menurut penggolongan hukumnya sendiri, sejalan pula dengan kesadaran hukum mereka sendiri. Sebab itu hukum perkawinan Islam berlaku bagi orang Islam. Hukum Perkawinan Hindu berlaku bagi umat Hindu dan seterusnya. Namun terhadap hukum kewarisan, tetap ada "legal choice". ${ }^{24}$ Dalam hal hukum publik, kita ingin melakukan unfikasi hukum. Artinya satu jenis hukum untuk semua penduduk dan warga negara. Di sinilah letaknya menurut Yusril Ihza Mahendra apa yang disebut dengan Transformasi kaidah-kaidah Syariat Islam menjadi Hukum Positif Nasional. Tentu tidak saja syariat Islam yang ditransformasikan, tetapi juga hukum eks kolonial yang sudah diterima masyarakat, asas-asas hukum adat dan berbagai konvensi internasional. ${ }^{25}$

Transformasi syariat Islam menjadi Hukum Positif ini telah dilakukan ketika Departemen Kehakiman menyusun Undang-undang Pemberantasan Terorisme. Para penyusunnya mentransformasikan kaidah-kaidah syariat Islam tentang kategori pidana yang luar biasa (extra ordinary crime), di samping juga mentransformasikan Statuta Roma dan Konvensi PBB tentang Trans National Organized Crime. Asas-asas hukum pidana warisan Belanda juga menjadi acuan. ${ }^{26}$ Di dalam Undang-undang Lalu Lintas, transformasi dari syariat Islam juga diberlakukan, prinsip utama Islam seperti dikatakan dalam hadis ialah, iman yang paling tinggi meyakini keesaan Tuhan, dan yang paling bawah adalah menyingkirkan sampah dan duri dari jalan lalu lintas manusia. Tujuan syariah antara lain adalah menegakkan "al Amru bil ma'ruf wa tanhauna 'anil munkar", yang artinya menegakkan kebaikan dan mencegah kemungkaran. Syariat menekankan prinsip kebaikan bagi kepentingan bersama (istihsan). Inilah asasasas syariah yang ditransformasikan ke dalam UU Lalu Lintas. ${ }^{27}$

Dalam pandangan Yusril, transformasi syariat menjadi hukum positif telah lazim terjadi dalam sejarah berbagai negara ${ }^{28}$. Yusril mengatakan mengingat banyaknya masyarakat pemeluk agama islam, tentu dalam pembentukan hukum nasional harus mengadopsi dari syariat Islam. Karena masyarakat yang beragama Islam tidak mungkin bisa menjalankan aturan hukum yang bertentangan dengan keyakinannya sendiri.

Yusril menjelaskan bahwa pentransformasian itu lebih jauh dari berbagai sumbangan pemikiran di bidang filsafat hukum dan asas-asas hukum, sebagai mana berkembang dalam fiqh dari zaman lampau, dapat pula memberikan sumbangan dalam merumuskan kaidah-kaidah hukum nasional kita dimasa sekarang dan masa yang akan datang. ${ }^{29}$ Oleh karena itu, sumbangsih pemikiran di bidang filsafat hukum dan asas-asas hukum sejalan dengan perkembangan hukum di Indonesia ini sebagaimana dalam perkembangan fiqh kontemporer.

Para ahli hukum berbeda pendapat dalam memberi arti hukum Islam. Sebagian mereka berpendapat bahwa hukum Islam itu merupakan pedoman moral, bukan hukum dalam pengertian hukum modern. Pendapat ini dikemukakan oleh Muhammad Khalid Mas'ud bahwa hukum Islam itu adalah "a system of

\footnotetext{
${ }^{24}$ Ibid.

25 Ibid.,

26 Ibid.,

27 Ibid.,

${ }^{28}$ Ibid., hlm 10

${ }^{29}$ Ibid.,
} 


\section{$\mathcal{H}$ urnal Negara dan Keadilan \\ p-ISSN 2302-7010 e-ISSN 2721-9801}

ethical or moral rules" 30 . Namun Yusril mengatakan ajaran Islam atau hukum berlandaskan doktrin tauhid, adalah ajaran tentang keesaan Tuhan. ${ }^{31}$ Menurut Muhammad Daud Ali, Islam tidak pernah memisahkan antara hal-hal yang disebut spiritual (kerohanian) dan material (kebendaan), religious (keagamaan) dengan profane (keduniaan) di dalam segala bidang. ${ }^{32}$ Atas dasar ajaran tersebut, hukum Islam yang merupakan bagian integral dari ajaran-ajaran Islam yang tidak memisahkan iman, moralitas, dan hukum dapat menyumbangkan sesuatu yang penting dalam menggali Pancasila sebagai sumber pembentukan hukum Nasional. Dengan kata lain Hukum yang akan diproduk di Negara kita haruslah mengandung dimensi keimanan dan moralitas. ${ }^{33}$

Dalam Buku Ensiklopedi Pemikiran Yusril Ihza Mahendra, Yusril membantah pernyataan mengenai beberapa perihal yang mengatakan kalau hukum Islam dijadikan sebagai bagian dari hukum nasional, dan syariat dijadikan sumber hukum dalam perumusan kaidah hukum positif, maka negara Indonesia akan menjadi Negara Islam. Yusril mengatakan selama ini hukum Belanda dijadikan sebagai hukum positif dan juga dijadikan sebagai sumber hukum, tetapi belum pernah kita mendengar orang mengatakan bahwa negara kita menjadi Negara Belanda. UU Pokok Agraria, terang-terangan menyebutkan bahwa UU itu dirumuskan berdasarkan kaidah-kadiah hukum adat, tetapi sampai sekarang belum pernah orang mengatakan Indonesa sudah menjadi Negara Adat.

Menurut Yusril: "Dahulu waktu saya menjadi menteri kehakiman selalu ada yang mengatakan bahwa kalau hukum Islam dijalankan nanti Indonesia akan menjadi negara Islam. Saya katakana bahwa hukum adat Jawa itu sudah berjalan dari jaman dahulu. Tidak pernah ada orang yang mengatakan Indonesia menjadi negara Jawa". ${ }^{34}$

Yusril menegaskan, mengingat hukum Islam itu adalah hukum yang hidup dalam masyarakat Indonesia, maka negara tidak dapat merumuskan kaidah hukum positif yang nyata-nyata bertentangan dengan kesadaran hukum rakyatnya sendiri. Demokrasi harus mempertimbangkan hal ini. Jika sebaliknya, maka negara kita akan menjadi negara otoriter yang memaksakan kehendaknya sendiri kepada rakyatnya.

Rahmawati Pardjaman mengatakan bahwa Transformasi hukum Islam sebagai salah satu tatanan hukum ke dalam hukum nasional, secara umum terakomodasi dalam sasaran pembangunan nasional di bidang hukum khususnya tentang materi hukum nasional. Namun penerapan dan penegakan hukum dalam masyarakat tergantung kepada empat unsur. Pertama, perangkat hukum yang menjamin kepastian, perlindungan, dan ketertiban hukum yang intinya keadilan dan kebenaran. Kedua, aparatur penegak hukum yang mampu dan/atau mempunyai kesanggupan menerapkan hukum dan menyelami rasa keadilan. Ketiga, kesadaran hukum masyarakat yang intinya menghargai dan mematuhi

${ }^{30}$ Muhammad Khalid Mas eeud, Islamic Legal Philosophy, a Study of Abû Ishâq alSyâtibî, Life and Tough, (Pakistan: Islamic Research Institute, 1977), h. 9. Dalam jurnal Rahmawati Pardjaman,

${ }^{31}$ Abbas, Hafid, et.all,. op.cit.,, hlm. 6.

${ }^{32}$ Mohammad Daud Ali, Hukum Islam : Pengantar Hukum Tata Negara dan Hukum Islam di Indonesia, hlm 23.

${ }^{33}$ Abbas, Hafid, et.all,. op.cit., hlm. 11.

${ }^{34}$ Wawancara dengan Prof Yusril Ihza Mahendra, secara daring (online) melalui aplikasi Zoom Meeting pada tanggal 15 Februari 2021 


\section{Hurnal Negara dan $\mathcal{X}$ eadilan \\ p-ISSN 2302-7010 e-ISSN 2721-9801}

hukum yang berlaku. Keempat, sarana dan prasarana yang dibutuhkan baik berupa kelembagaan maupun fisik. ${ }^{35}$

Pada buku Ensiklopedia Pemikiran Yusril Ihza Mahendra, Yusril mengatakan belum pernah dalam sejarah, hakim memutuskan perkara-perkara karena melanggar salah satu surah dan ayat tertentu di dalam Al Qur-an, atau menyebut telah melanggar hadits Nabi dalam Shahih Bukhari. Tentu Al Qur-an dan As Sunnah mengandung arahan dan pokok-pokok tentang hukum acara, tetapi perlu dieksplisitkan agar dapat dilaksanakan sebagai hukum prosedur dalam sidang pengadilan. Hal ini membuktikan bahwa dalam Al-Qur'an dan Hadis tidak hanya membahas mengenai urusan ibadah antara hamba dan penciptanya, tetapi juga membahas kemaslahatan hambaNya di dunia dan di akhirat. Karena hakim tidak boleh memutuskan suatu perkara yang bertentangan dengan kepercayaan masyarakat itu sendiri.

Yusril Ihza Mahendra mengatakan proses pentransformasian syariat Islam ke hukum Nasional memerlukan berbagai proses perumusan. Yaitu dengan memformulasikan kaidah-kaidah hukum islam, kemudian menuangkannya menjadi sesuatu yang dapat dilaksanakan dalam kenyataan

Menurutnya, transformasi Syari'at Islam ke dalam Hukum Nasional memerlukan banyak hal, baik secara sosiologis maupun politis. Yaitu, Memerlukan institusi-institusi, lembaga-lembaga, dan organiasi kekuasaan. Organiasi kekuasan inilah yang disebut dengan negara atau daulah yang sah untuk membentuk dan menegakkan suatu norma hukum, bila perlu dengan paksaan, supaya norma hukum itu dapat dijalankan dan dipatuhi oleh publik. Yusril Ihza Mahendra mengatakan, proses pembentukan peraturan perundang-undangan merupakan sebuah proses politik. Pada masa pemerintahan orde baru dulu, hanya pemerintah yang bisa mengajukan Rancangan Undang-Undang (RUU). Namun, sekarang ini badan legislasi (baleg), fraksi, anggota DPR antara 15-20 orang boleh mengajukan RUU. "Proses pembentukan peraturan perundang-undangan itu merupakan sebuah proses politik.. Pada jaman orde baru dahulu hanya pemerintah yang berhak mengajukan RUU. Namun pada masa sekarang ini baleg boleh mengajukan, fraksi boleh mengajukan. Anggota DPR saja 15 atau 20 orang boleh mengajukan RUU itu". ${ }^{36}$

Yusril Ihza Mahendra meyakini bahwa proses transformasi Hukum Islam kedalam Hukum Nasional sangat mungkin untuk dilakukan. Hal ini memerlukan kesadaran dengan menumbuhkan jiwa Islami kepada para penguasa, karena mereka yang punya hak dalam perancangan suatu peraturan atau perundangundangan. Namun, kebanyakan orang sekarang ingin menerapkan syariat Islam tetapi caranya tidak konstitusional. Jadi, menurut "saya (baca: Yusril Ihza Mahendra) sebenarnya tidak ada yang sulit asal kita mau bekerja. Cuma kadangkadang kita ini berfikir yang naif begitu. Teriak-teriak kesana. Teriak-teriak dijalan. Ya mau menerapkan syariat teriak saja di mimbar-mimbar". ${ }^{37}$

Dalam wawancara tersebut, Yusril teringat cerita Muhammad Natsir pada tahun 1946. Ketika itu beliau (Muhammad Natsir) menjadi Menteri Penerangan.

\footnotetext{
${ }^{35}$ Rahmawati Pardjaman, Loc.cit

36 Wawancara dengan Prof Yusril Ihza Mahendra, secara daring (online) melalui aplikasi Zoom Meeting pada tanggal 15 Februari 2021

${ }^{37}$ Wawancara dengan Prof. Yusril Ihza Mahendra, secara daring (online) melalui aplikasi Zoom Meeting pada tanggal 15 Februari 2021
} 


\section{$\mathcal{H}$ urnal Negara dan Keadilan \\ p-ISSN 2302-7010 e-ISSN 2721-9801}

Beliau datang ke Jakarta untuk menjadi khatib sholat Jumat. Di Masjid Al Makmur, Tanah Abang. Turun dari mimbar, beliau dikerumuni jamaah. Ditanya oleh seorang jamaah, Bung Natsir, kenapa bung Natsir ini jadi menteri? Padahal saat itu, bung Natsir adalah seorang ulama' dan kyai. Muhammad Natsir dengan tegas menjawab bahwa sekarang ini kita sudah merdeka, negara punya kita bukan punya Belanda lagi. Kalau saya hanya jadi kyai maka ajaran agama itu hanya akan keluar dari mimbar ke mimbar, masjid ke masjid. Jadi, Muhammad Natsir menjadi menteri karena ingin ajaran agama Islam masuk ke kantor-kantor pemerintahan dan akan keluar menjadi kebijakan-kebijakan negara.

Yusril Ihza Mahendra telah berpengalaman melakukan proses transformasi Syari'at Islam ke dalam Hukum Nasional, yaitu ketika beliau menjabat sebagai Meneteri Kehakiman untuk menyusun Undang-undang Pemberantasan Terorisme. Para penyusun mentransformasikan kaidah-kaidah syariat Islam tentang kategori pidana yang luar biasa (extra ordinary crime). Disamping itu juga mentransformasikan Statuta Roma dan Konvensi PBB tentang Trans National Organized Crime. Asas-asas hukum pidana warisan Belanda juga dijadikan acuan. ${ }^{38}$ Jadi, masalah pentransformasian yang telah dilakukan di Indonesia tidak terfokus hanya kepada masalah perdata saja, tentu dengan perkembangan jaman. Satu per satu kaidah syariat Islam akan masuk kepada hukum Nasional.

Yusril Ihza Mahendra juga memberikan contoh bahwa dalam UndangUndang Lalu Lintas, sudah ditransformasikan dari syariat Islam. Prinsip utama ajaran Islam sepeti dikatakan dalam hadits ialah, bahwa cabang iman yang paling tinggi adalah meyakini keesaan Tuhan, dan yang paling bawah ialah menyingkirkan sampah dan duri dari jalan lalu lintas manusia. Tujuan syari'at antara lain ialah menegakkan 'al-Amru bil ma'ruf wan-Nahyu 'anil munkar' (menegakkan kebaikan dan mencegah kemungkaran). Maksud dari filsafat yang disampaikan Yusril ialah syari'at menekankan prinsip kebaikan bagi kepentingan bersama (istihsan). Inilah asas-asas syari'ah yang ditransformasikan ke dalam UU Lalu Lintas. Orang berjalan sebelah kiri misalnya, tidak ada dalam syari'ah. Juga tidak ada dalam hukum adat. Tetapi jalan di sebelah kiri diperkenalkan oleh hukum Belanda, sejak tahun 1912. Semua asas-asas inilah yang ditransformasikan ke dalam hukum positif nasional.

Dalam Undang-Undang Lalu Lintas Nomor 22 Tahun 1996 yang dimana bait dari pasalnya ialah untuk mengutamakan keselamatan masyarakat dalam berlalu lintas. Yang sudah jelas bahwa Lalu Lintas dan Angkutan Jalan sebagai bagian dari sistem transportasi nasional harus dikembangkan potensi dan perannya untuk mewujudkan keamanan, keselamatan, ketertiban, dan kelancaran berlalu lintas dan Angkutan Jalan dalam rangka mendukung pembangunan ekonomi dan pengembangan wilayah. Begitu menjadi Undang-Undang positif Lalu Lintas, Undang-Undang itu berlaku bagi semua orang, tidak peduli agamanya. Maka Yusril mengatakan Undang-Undang Lalu Lintas itu tergolong ke dalam hukum publik, yang kita berkeinginan adanya unifikasi atau penyatuan. Yusril menekankan perlu kiranya pendalaman terhadap teori ilmu hukum, sosiologi

38 Rahmawati Pardjaman, Transformasi Nilai-Nilai Syariah ke dalam Sistem Hukum Nasional: Sebuah Pendekatan Hermeneutika, Al-Adalah 11 (2013 


\section{Hurnal Negara dan $\mathcal{X}$ eadilan \\ p-ISSN 2302-7010 e-ISSN 2721-9801}

hukum, dan filsaat hukum. Sangat penting untuk memahami hal ini, agar tidak terjadi kesalahpahaman. ${ }^{39}$

\section{PENUTUP}

Yusril Ihza Mahendra adalah seorang pakar hukum tata negara, intelektual, cendekiawan muslim, dan politikus Indonesia. Walaupun memiliki kemampuan membaca, menelaah, dan menjelaskan kitab-kitab klasik dan referensi ilmu-ilmu islam, Yusril sering mengatakan bahwa ia bukan ahli di bidang hukum Islam. Hal ini dikarenakan secara formal fokus kajian akademisnya adalah hukum tata negara. Namun terkait dengan transformasi syari'at Islam ke dalam hukum nasional terdapat titik singgungnya dengan hukum tata negara. Selain terkait juga dengan sejarah hukum, sosiologi hukum, dan filsafat hukum yang menjadi minat kajian akademisnya selma ini.

Dari hasil kajian dan pembahasan dalam penelitian ini, peneliti dapat menarik kesimpulan sebagai berikut:

1) Menurut Prof. Yusril Ihza Mahendra pengertian dan batasan Syari'at Islam dalam kaitan dengan penelitian ini adalah ayat-ayat Al Qur-an dan haditshadits Rasulullah SAW yang di dalamnya mengandung suatu norma hukum. Apabila suatu ayat atau hadits Rasulullah SAW tidak mengandung suatu norma hukum, maka ayat atau hadits tersebut tidak termasuk sebagai syari'at.

2) Menurut pemikiran Yusril Ihza Mahendra, sepanjang telaahnya tentang sejarah hukum di Indonesia sejak berabad-abad yang lalu hukum Islam telah menjadi hukum yang hidup di tengah-tengah masyarakat Islam di Indonesia. Hukum Islam adalah hukum yang hidup, berkembang, dikenal dan ditaati oleh umat Islam di negara ini.

3) Menurut pemikiran Yusril Ihza Mahendra transformasi syari'at Islam ke hukum nasional sangat relevan untuk dilaksanakan. Mengingat bahwa Indonesia adalah negara yang mayoritas berpenduduk muslim. Tentu dalam pembuatan suatu undang-undang akan berjalan dengan baik dan efektif apabila tidak bertentangan dengan keyakinan masyarakat itu sendiri. Karena hukum Islam adalah hukum yang hidup di tengah-tengah masyarakat Indonesia. Namun demikian, pentransformasian syari'at Islam ke dalam hukum nasional itu memerlukan berbagai proses perumusan. Yaitu dengan memformulasikan kaidah-kaidah hukum islam, kemudian menuangkannya menjadi sesuatu yang dapat dilaksanakan dalam kenyataan. Selain itu diperlukan banyak hal, baik secara sosiologis maupun politis. Yaitu, memerlukan institusi-institusi, lembaga-lembaga, dan organiasi kekuasaan, yang disebut dengan negara atau daulah yang sah untuk membentuk dan menegakkan suatu norma hukum, bila perlu dengan paksaan, supaya norma hukum itu dapat dijalankan dan dipatuhi oleh publik. Lebih jauh, proses pembentukan peraturan perundang-undangan merupakan sebuah proses politik. Hal ini memerlukan kesadaran dengan menumbuhkan jiwa Islami kepada para penguasa, karena mereka yang punya hak dalam perancangan suatu peraturan atau perundang-undangan. 


\section{Jurnal Negara dan $\mathcal{X}$ eadilan \\ p-ISSN 2302-7010 e-ISSN 2721-9801}

\section{Buku}

\section{DAFTAR PUSTAKA}

Abbas, Hafid, et.al, Ensiklopedia $\quad$ Pemikiran Yusril Ihza Mahendra, Buku Tiga, Jakarta: Pro Deleader.

Ali, Zainuddin, Hukum Perdata Islam di Indonesia, Cetakan kelima, Jakarta: Remaja Rosdakarya, 2006

Mohammad Daud Ali, Hukum Islam : Pengantar Hukum Tata Negara dan Hukum Islam di Indonesia.

Satjipto Rahardjo, Ilmu Hukum, Bandung: Citra Aditya, 2000,

Soerjono Soekanto dan Sri Mamudji. Penelitian Hukum Normatif Suatu Tinjauan Singkat. Jakarta: Rajawali Pers, 2006.

\section{Jurnal}

Muhammad Khalid Maseeud, Islamic Legal Philosophy, a Study of Abû Ishâq alSyâtibî, Life and Tough, (Pakistan: Islamic Research Institute, 1977), h.9. Dalam jurnal Rahmawati Pardjaman,

Rahmawati Pardjaman, Transformasi Nilai-Nilai Syariah ke dalam Sistem Hukum Nasional: Sebuah Pendekatan Hermeneutika, Al-Adalah 11 (2013

\section{Website}

Anonim, 2013. "Pendekatan dalam Penelitian Hukum". https://ngobrolinhukum. wordpress.com/2013/12/16/ pendekatan-dalam-penelitian-hukum/. Diakses $12 / 12 / 2020$

BPS. 2010. Penduduk Menurut Wilayah dan Agama yang dianut. https://sp2010.bps.go.id/ index.php/site/ tabel?tid=321\&wid=0. 03/11/2020

Fathoni R.S. Piagam Jakarta 22 Juni 1945. 2018.https://wawasansejarah.com/ piagam-jakarta/. 03/11/2020 